\title{
SYNTHESIS OF 2-HIDROXYXANTHONE FROM XANTHONE AS A BASIC MATERIAL FOR NEW ANTIMALARIAL DRUGS
}

\begin{abstract}
AMANATIE AMANATIE ${ }^{1}$, JUMINA JUMINA ${ }^{2}$, MUSTOFA MUSTOFA ${ }^{3}$, HANAFI M $^{4}$, LA ODE KADIDAE ${ }^{5}$, SAHIDIN I $^{6 *}$
${ }^{1}$ Department of Chemistry, Faculty of Mathematics and Natural Sciences, Yogyakarta State University, Yogyakarta 55281, Indonesia. ${ }^{2}$ Department of Chemistry, Faculty of Mathematics and Natural Sciences, Gadjah Mada University, Yogyakarta 55281, Indonesia. ${ }^{3}$ Department of Medicine, Faculty of Medicine, Gadjah Mada University, Yogyakarta 55281, Indonesia. ${ }^{4}$ Pusat Penelitian Kimia, Lembaga Ilmu Pengetahuan Indonesia, Serpong, Tanggerang 15314, Indonesia. ${ }^{5}$ Department of Chemistry, Faculty of Mathematics and Natural Sciences, Universitas Halu Oleo, Kampus Baru Anduonohu, Kendari, Sulawesi, Tenggara 93232, Indonesia. ${ }^{6}$ Department of Pharmacy, Faculty of Pharmacy, Universitas Halu Oleo, Kampus Baru Anduonohu, Kendari, Sulawesi, Tenggara 93232, Indonesia. Email: sahidin02@yahoo.com
\end{abstract}

Received: 12 May 2017, Revised and Accepted: 01 September 2017

\section{ABSTRACT}

Objective: The purpose of this research is to synthesize 2-hydroxyxanthone from xanthone and to evaluate its antiplasmodial activity.

Methods: The synthesis of 2-hydroxyxanthone followed the sequence of these synthetic stages, namely: 2-nitroxanthone, 2-aminoxanthone, and 2-hydroxyxanthone. The products were separated by chromatography methods including thin layer chromatography and vacuum liquid chromatography. Compound structures of the isolated products were determined based on their infrared and nuclear magnetic resonance spectra. To support these findings, the spectra were also matched to the corresponding data from literatures. The biological properties of the synthetic compound were evaluated toward Plasmodium falciparum 3D7.

Results: 2-nitroxanthone was obtained as a brownish-yellow crystal in $69.00 \%$ yield with Madhya Pradesh of $181^{\circ} \mathrm{C}$. Reduction of 2 -nitroxanthone using $\mathrm{SnCl}_{2} \cdot 2 \mathrm{H}_{2} \mathrm{O} /$ hydrogen chloride produced 2-aminoxanthone as a pale-yellow solid in $60.60 \%$ yield. Finally, the desired 2-hydroxyxanthone was achieved by initially reacting 2-aminoxanthone with sodium nitride to produce diazonium salt. Then, hydrolysis of the salt yielded 2-hydroxyxanthone as a white solid in $69.81 \%$ yield. Synthesis of 2-hydroxyxanthone from xanthone had an overall yield of $38.35 \%$. In vitro antiplasmodial assay against P. falciparum 3D7 showed that the half maximal inhibitory concentration value was $0.44 \mu \mathrm{g} / \mathrm{mL}$.

Conclusions: An antimalarial compound (2-hydroxyxanthone) was successfully synthesized from xanthone in three steps of synthetic reactions, i.e., the formation of 2-nitroxanthone, 2-aminoxanthone, and 2-hydroxyxanthone.

Keywords: 2-nitroxanthone, 2-aminoxanthone, 2-hydroxyxanthone, in-vitro, antiplasmodium, Plasmodium falciparum 3D7.

(c) 2017 The Authors. Published by Innovare Academic Sciences Pvt Ltd. This is an open access article under the CC BY license (http://creativecommons. org/licenses/by/4. 0/) DOI: http://dx.doi.org/10.22159/ajpcr.2017.v10i12.19858

\section{INTRODUCTION}

Malaria is a kind of disease, which still threatens residents in both developing and developed countries. In 2010, malaria caused 660,000 deaths, especially in children. According to the World Health Organization (WHO), malaria is actually a preventable and treatable disease. Prevention and control of this disease may decrease malaria cases in various places [1], and the WHO targets a $50 \%$ or more reduction in cases and deaths from malaria in 2000 to 2010 and $75 \%$ or more between year 2000 and 2015 [2]. Efforts to overcome malaria can be done medically and non-medically. Medical efforts, among others, are done by finding new antiplasmodium through isolation from nature and modifying it, and also synthesizing or derivatizing existing antiplasmodium compounds [3-5].

The natural product compounds that have anti-plasmodial potencies are lignan [6], quinolone [7], and xanthone derivatives [8]. Xanthone derivatives have potency not only as antiplasmodium but also as cyclooxygenase- 2 inhibitor agents [9]. Tropical plants that have been used as a traditional antimalarial drug, especially in Indonesia are Alectronserratus [10], Artocarpus heterophillus, Artocarpus altilis, and Artocarpus camansi [11], and also Garcinia dulcis (Gutteferae). Further study of $G$. dulcis, potency as antimalarial have been done by in vivo test against Swiss Webster mice [12]. Phytochemical studies show that Garcinia plants commonly produce xanthone compounds. For example, the leaves of $G$. dulcis produce terpenoids, benzophenone, biflavonoid, and xanthone [13]. 7-0-methylgulinone-E, a new type of xanthone was reported from Garcinia cowa [14,15]. This compound was isolated from the bark of the plant and in fact, this xanthone was found to be active as an antimalarial against Plasmodium falciparum with half maximal inhibitory concentration $\left(\mathrm{IC}_{50}\right.$ ) values ranging from $1.50-3.00 \mu \mathrm{g} / \mathrm{mL}$. Moreover, 1,3,7-trihydroxy-prenyl-xanthoneobtained from Calophytae caledonicum had activity as antimalarial with $\mathrm{IC}_{50}$ of $1.0 \mu \mathrm{g} / \mathrm{mL}$ [8].

A thoroughly study of the correlation between xanthone derivatives with antiplasmodial activity showed that the antimalarial activities of hydroxyxanthones were affected by the amount of hydroxyl groups in the xanthones celletone. In general, the more hydroxyl groups attached to the xanthone framework, the better anti-plasmodial activity of the compound [8]. One of the most potent antimalarial compounds derived from xanthone compounds against $P$. falciparum is 2-hydroxyxanthone from $G$. dulcis root barks with $\mathrm{IC}_{50}$ value $0.44 \mu \mathrm{g} / \mathrm{mL}$ [15]. This compound has only one hydroxyl group, so that its anti-malarial activity may be increased by adding hydroxyl groups as substituents. However, the quantity of these compounds that could be isolated from natural products is very low. One way to increase the quantity is through synthesis.

The synthesis of 2-hydroxyxanthone from xanthone and its biological activity evaluation against $P$. falciparum strain 3D7 has not been reported yet. This article discussed 2-hydroxyxanthone synthesis and its anti-plasmodium activity evaluation. The steps of the synthesis were following this sequential order. First, xanthone was synthesized from 2-phenoxybenzoic acid, followed by preparation of 2-nitroxanthone, 
then 2-aminoxanthone and finally 2-hydroxyxanthone. Furthermore, its antiplasmodial potency was evaluated toward in vitro P. falciparum strain 3D7.

\section{MATERIALS AND METHODS}

\section{General procedures}

Thin layer chromatographic (TLC) analyses were performed on Kiesel gel $60 \mathrm{~F}_{254}$ plates from Merck. Detection was carried out under ultra violet (UV) light. Column chromatography for substance purifications was performed on silica gel $60 \mathrm{~N}, 40-50 \mu \mathrm{m}$. Solvents' evaporation was performed using Iwaki Rotary Evaporator REN-1000 with reduced pressure. Perkin-Elmer spectrum one Fourier-transform infrared (IR) spectrophotometers was used to record infrared spectra. JEOL nuclear magnetic resonance (NMR) of JNM ECA $500 \mathrm{MHz}$ was utilized in analysis of ${ }^{1} \mathrm{H}$ and ${ }^{13} \mathrm{C}$ NMR spectra. The operations of the JEOL spectrophotometer were at $500 \mathrm{MHz}$ for ${ }^{1} \mathrm{H}$ NMR and at $125 \mathrm{MHz}$ for ${ }^{13} \mathrm{C}$, using acetone- $d_{6}$ as solvent and TMS as internal standard. Anti-plasmodial evaluation used the standard facilities for in vitro antiplasmodium test.

\section{Materials}

Glacial acetic acid (Merck), dichloromethane $\left(\mathrm{CH}_{2} \mathrm{Cl}_{2}\right)$ (Merck), ethanol (Merck), diethylether (Merck), hydrochloric acid (Merck), $\mathrm{Na}_{2} \mathrm{SO}_{4}$ anhydrous (Merck) $\mathrm{SnCl}_{2} \cdot 2 \mathrm{H}_{2} \mathrm{O}$ (Merck), sodium nitride $\left(\mathrm{NaNO}_{2}\right.$ ) (Merck), $\mathrm{NaOH}$ (Merck), hydrazinium mono formate (Merck), and distilled water. The materials used for in vitro antiplasmodium test including chloroquine diphosphate, $10 \%$ serum, Medium roswell park memorial institute 1640 and Giemsa.

\section{Experiments}

\section{Synthesis of 2-nitroxanthone}

The slurry mixture of $4.90 \mathrm{~g}$ (25 mo1) of the xanthone in $10 \mathrm{~mL}$ of glacial acetic acid was reacted at $0^{\circ} \mathrm{C}$ (ice cooling) with $1.039 \mathrm{ml}$ nitric acid (concentrated). To the reaction mixture, $1.31 \mathrm{~mL}$ of sulphuric acid (concentrated) was added, and the mixture was stirred for $4 \mathrm{hrs}$. The progress of the synthetic reaction was monitored with TLC in which after starting to forma yellow solution, the product was tested with TLC using $\mathrm{CH}_{2} \mathrm{Cl}_{2}$ as an eluent and the $\mathrm{Rf}$ was compared to the starting material (xanthone) Rf. Once the TLC indicating there was a difference in the Rf value, then the heating was stopped and let it overnight to cool to room temperature. The resulted yellow solids were filtered and washed it in a sequential order with $25 \mathrm{~mL}$ of dichloromethane, $10 \mathrm{~mL}$ of water, $10 \mathrm{~mL}$ of ethanol, and $10 \mathrm{~mL}$ of diethylether. The organic layer was collected and dried with $\mathrm{Na}_{2} \mathrm{SO}_{4}$ anhydrous. After filtration, the solvents were removed through evaporation with Buchi rotary evaporator. The obtained solid was recrystallized to remove the reaction residue; finally, the desired product was obtained. Identification of the products was determined by measuring its melting point and assessing its UV-vis and IR spectra.

\section{Synthesis of 2-aminoxanthone}

2-Nitroxanthone (10 $\mathrm{mg}, 0.0413 \mathrm{mmol}$ ) was suspended in $12.5 \mathrm{~mL}$ of ethanol, stirred and cooled at $5{ }^{\circ} \mathrm{C}$. The cooled suspension was added drop wisely with $\mathrm{SnCl}_{2} .2 \mathrm{H}_{2} \mathrm{O}(0.6688 \mathrm{~g}, 0.0413 \mathrm{mmol}$ ) in $1.25 \mathrm{~mL}$ hydrogen chloride ( $\mathrm{HCl}$ ) (concentrated) at maintained temperature under $100^{\circ} \mathrm{C}$. After completion of the addition of $\mathrm{SnCl}_{2} \cdot 2 \mathrm{H}_{2} \mathrm{O}$, the reaction mixture was refluxed it at $80^{\circ} \mathrm{C}$ for $2 \mathrm{hrs}$ and let it to cool to room temperature overnight. After that, it was diluted with distilled water, extracted with $15 \mathrm{~mL}$ dichloromethane, filtered, and extracted with $15 \mathrm{~mL}$ of ethyl acetate. The organic layer was dried with $\mathrm{Na}_{2} \mathrm{SO}_{4}$ anh. and after filtration the solvents were removed by evaporation. The obtained product was dried. The product was characterized using IR spectrophotometer

\section{Synthesis of 2-hydroxyixanthone}

Into a three-neck flask containing 2-aminoxanthonee $0.01 \mathrm{~g}$, $0.00005 \mathrm{~mol}$ ) suspended in $\mathrm{HCl}, 10 \mathrm{~mL}$ of $\mathrm{NaNO}_{2} 2.8 \mathrm{M}$ was added at $5^{\circ} \mathrm{C}$ and the solution changed entirely to yellow. The reaction mixture was stirred at $5^{\circ} \mathrm{C}$ for 30 minutes and added with15 $\mathrm{ml}$ of $\mathrm{HCl} 1 \mathrm{M}$ and then cooled. The reaction mixture was continually stirred at $5^{\circ} \mathrm{C}$ for $1 \mathrm{hr}$, and acidified with phosphoric acid. The product was recrystallized with ethanol-distilled water. Furthermore, the crystal was analyzed using IR and NMR spectrometer.

\section{In vitro antiplasmodial activity test}

Testing the effect of in vitro antiplasmodium of the compound against $P$. falciparum 3D7 utilized a procedure outlined by Trager and Jensen and it was modified by Waruyanti $[16,17]$. To determine the $\mathrm{IC}_{50}$ (concentration of test compound which could inhibit parasitic growth by $50 \%$ ), the obtained data were analyzed using probit analysis method.

\section{RESULTS}

Rendement of reaction steps in 2-hydroxyxanthone synthesis are displayed in Table 1.

\section{${ }^{1}$ HNMRdata of 2-nitroxanthone}

The ${ }^{1} \mathrm{HNMR}$ spectrum of 2-nitroxanthone $(500 \mathrm{MHz}) \delta_{\mathrm{H}}(\mathrm{ppm}) 8.75(2 \mathrm{H}$, d, $J=2.3, \mathrm{H}_{1}$ and $\left.\mathrm{H}_{8}\right) ; 8.36\left(1 \mathrm{H}, \mathrm{d}, J=8.3, \mathrm{H}_{4}\right) ; 8.34\left(2 \mathrm{H}, \mathrm{dd}, J=8.3,2.3, \mathrm{H}_{3}\right.$ and $\left.\mathrm{H}_{6}\right) ; 7.30(1 \mathrm{H}, \mathrm{d}, J=8.3) ; 7.10\left(1 \mathrm{H}, \mathrm{d}, J=8.3, \mathrm{H}_{7}\right)$; and $6.86(1 \mathrm{H}, \mathrm{d}, J=8.3$, $\mathrm{H}_{5}$ ).

\section{${ }^{1} \mathrm{H}$ and ${ }^{13} \mathrm{C}$ NMR data of 2-hydroxyxanthone}

The ${ }^{1} \mathrm{HNMR}$ spectrum of 2-hydroxyxanthone $(500 \mathrm{MHz}) \delta_{\mathrm{H}}(\mathrm{ppm})$ : $11.93(1 \mathrm{H}, \mathrm{s}, \mathrm{O}-\mathrm{H}) ; 7.56(2 \mathrm{H}, J=8.3 \mathrm{~Hz}) ; 7.28(2 \mathrm{H}, J=8.3 \mathrm{~Hz}) ; 7.20(1 \mathrm{H}, \mathrm{s})$; $6.91(1 \mathrm{H}, J=8.3 \mathrm{~Hz})$; and $6.85(1 \mathrm{H}, J=8.3 \mathrm{~Hz})$.The spectrum of ${ }^{13} \mathrm{C}-\mathrm{NMR}$ (JEOL, JNM ECA $125 \mathrm{MHz}$ ) showed aryl carbons at $\delta_{c} 96 ; 106 ; 110 ; 117$; 137 and $155 \mathrm{ppm}$. The peak at $\delta_{\mathrm{c}} 179$ came from the carbonyl group while the peak at $\delta 155 \mathrm{ppm}$ was the peak for the carbon next to the hydroxyl group.

\section{DISCUSSION}

\section{Synthesis of 2-hydroxyxanthone}

Nitration of xanthone with concentrated nitric acid was conducted at $5^{\circ} \mathrm{C}$.This was performed by adapting No $\mathrm{K}$, Noh $\mathrm{Y}$ and Firdaus method $[18,19]$. The nitration product was a brownish-yellow crystal in $69.71 \%$ yield, with Madhya Pradesh of $181^{\circ} \mathrm{C}$. The product was characterized using UV-Vis and IR spectrometers. From UV-Vis spectra, it was found that there were 2 maximum wavelengths at 215 and 311 $\mathrm{nm}$. The appearance of the two peaks agreed with those of Harborne findings [20], namely, at 202-215; 254-258; 278-284; and 330-358 nm. The IR spectrum of the product showed strong absorption of carbonyl group at $1689 \mathrm{~cm}^{-1}$, while aromatic-ether group absorbed at 1288 and $1087 \mathrm{~cm}^{-1}$. The presence of strong absorption bands at 1543 and $1350 \mathrm{~cm}^{-1}$ was from the vibration of nitro groups.

The nitration mechanism was displayed in Fig. 1. The concentrated nitric acid acted as a direct nitrating agent. The formed nitronium agent would be attacked by the aromatic ring of xanthone to give 2-nitroxanthone.

Table 1: Reaction products (\%) of each reaction step

\begin{tabular}{llll}
\hline Source of compound & \multicolumn{2}{l}{ Yiled (\%) } & 2-hydroxyxanthone \\
\cline { 2 - 4 } & 2-nitroxanthone & 2-aminoxanth one & 69.81 from 2-aminoxanthone \\
\hline Xanthone & 69.71 from xanthone & 78.81 from 2-nitroxanthone &
\end{tabular}




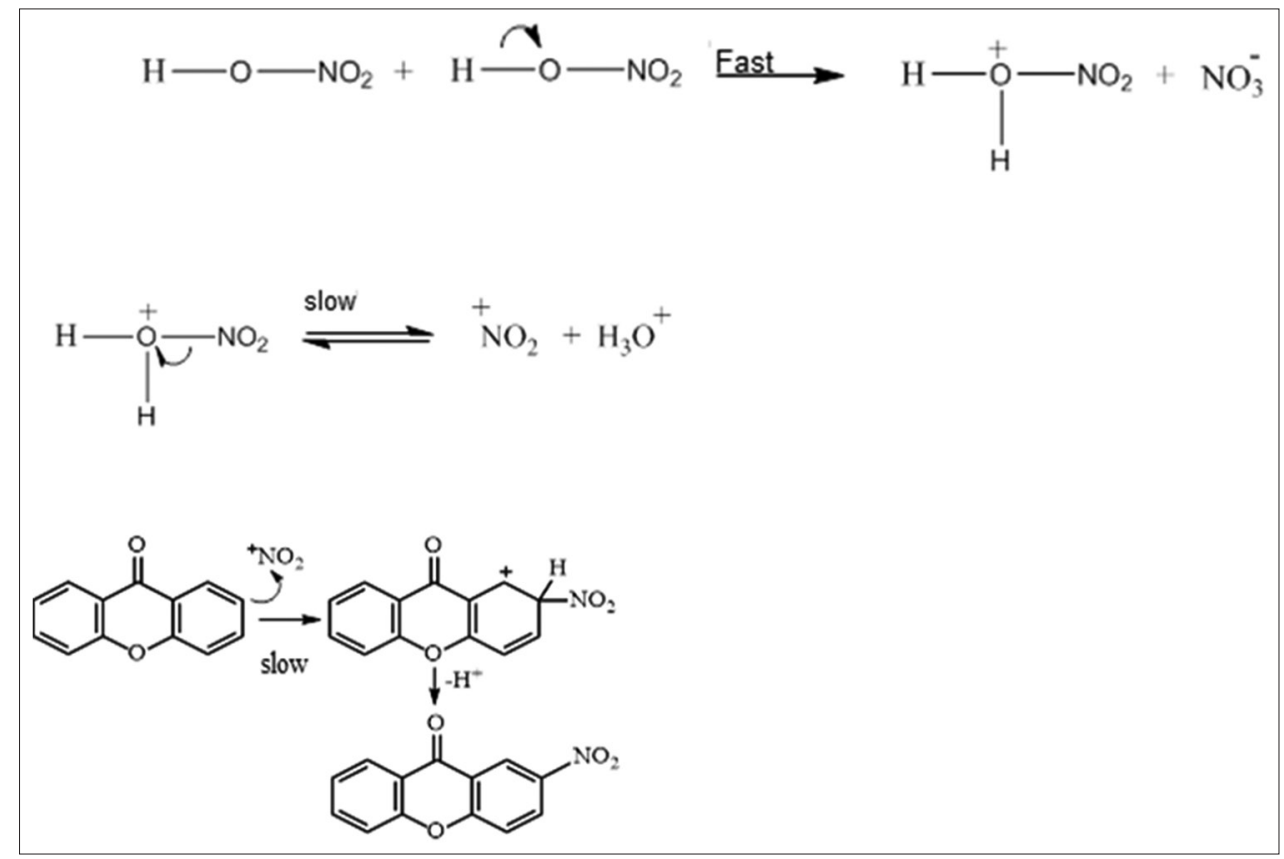

Fig. 1: Reaction mechanism of xanthone nitration

However, the formation of nitronium ion was relatively slow, thus the yield was not optimal. For this reason a mixture of sulfuric acid and nitric acid was required the reaction rate-stopping-agent.

Conversion of aliphatic nitro group into aliphatic amino group could be carried out using boron as a reductor in THF, while aromatic nitro group was usually performed using $\mathrm{Zn}$ as a reductor in neutral condition $[17,21]$ or $\mathrm{Zn}-\mathrm{NH}_{4} \mathrm{Cl} / \mathrm{H}_{2} \mathrm{O}$ at $50-55^{\circ} \mathrm{C}$. The reduction of nitro group could also be done using $\mathrm{SnCl}_{2} 2 \mathrm{H}_{2} \mathrm{O} / \mathrm{HCl}[13,14]$. In this research, the reduction of 2-nitro-xanthone was employed 3 equivalent of $\mathrm{SnCl}_{2} \cdot 2 \mathrm{H}_{2} \mathrm{O}$ in $\mathrm{HCl}$ per one nitro group. 2-Aminoxanthone was obtained as a pale-yellow solid in $60.60 \%$ yield. The solid product was slightly soluble in ethyl acetate. The low yield was probably due to the less solubility of product in extractor solvent and the competition with the formation of $\mathrm{Sn}(\mathrm{OH})_{2}$. Absorption band in IR spectrum at $3093 \mathrm{~cm}^{-1}$ confirmed the existence of the amino group of the 2-aminoxanthone. The presence of this group and the disappearance of a band at $1543 \mathrm{~cm}^{-1}$ from nitro group, indicated that the nitro group has been completely reduced into amino group. The vibrations of C-N and C-O bonds were shown by the presence of the absorption band sat 1288 and $1234 \mathrm{~cm}^{-1}$, respectively. Based on the IR spectrum, it seemed that the desired product of 2-aminoxanthonewas successfully achieved from the reduction of 2-nitroxanthone using $\mathrm{SnCl}_{2} .2 \mathrm{H}_{2} \mathrm{O} / \mathrm{HCl}$, with78.81\% yield. The scheme of the formation of 2-aminoxanthone was presented in Fig. 2.

2-Aminoxanthoneas the product of 2-nitroxanthone reduction was then reacted with $\mathrm{NaNO}_{2}, \mathrm{HCl}$, and $\mathrm{H}_{3} \mathrm{PO}_{4}$ to yield 2-hydroxyxanthone, as presented in Fig. 3.

2-Hydroxyxanthone could be synthesized from aminoxanthones with $\mathrm{NaNO}_{2}$ and hydrochloric acid through diazonium salt. This compound was obtained by reacting 2-aminoxanthone with $\mathrm{NaNO}_{2}$ to first produce its diazonium salt. Then, hydrolysis of the salt gave 2-hydroxyxanthone as the desired product. The product was a white solid in $69.81 \%$ yield. The IR spectrum showed that the absorption at $3433 \mathrm{~cm}^{-1}$ indicated the stretch of $\mathrm{OH}$, while the stretching of aromatic $\mathrm{C}=\mathrm{C}$ appeared at $1620 \mathrm{~cm}^{-1}$.

The spectrum of ${ }^{1} \mathrm{H}-\mathrm{NMR}$ (JEOL, JNM ECA $500 \mathrm{MHz}$ ), showed that the aryl protons appeared in the region of $\delta 6.85-7.56 \mathrm{ppm}$. In this region, there were 4 doublet at $\delta_{\mathrm{H}} 6.85(2 \mathrm{H}, J=8.3 \mathrm{~Hz}), 6.91(2 \mathrm{H}, J=8.3 \mathrm{~Hz})$,

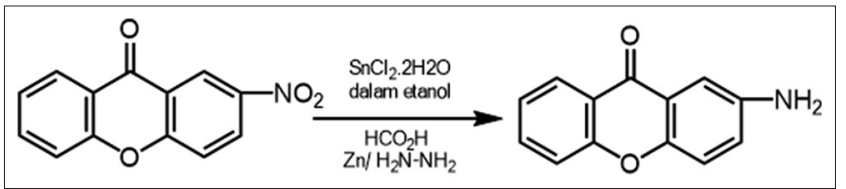

Fig. 2: Reduction of 2-nitroxanthone into 2-aminoxanthone using $\mathrm{SnCl}_{2} \cdot 2 \mathrm{H}_{2} \mathrm{O} / \mathrm{HCl}$

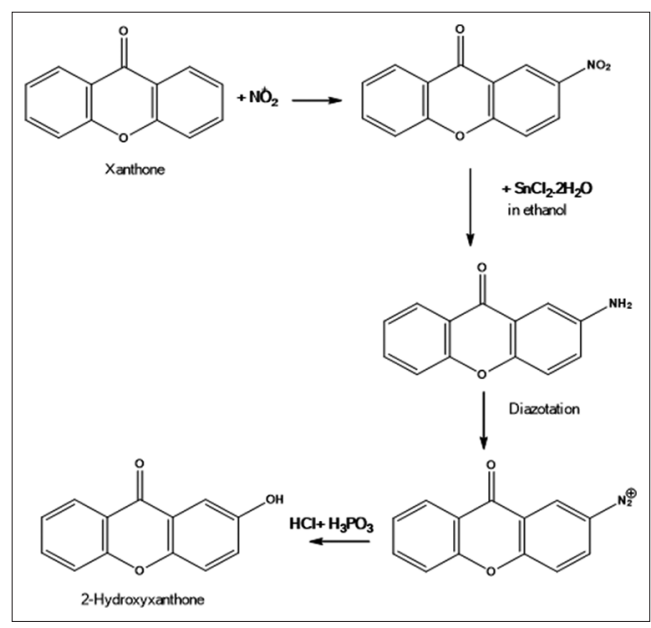

Fig. 3: Reaction of 2-hydroxyxanthone

$7.28(2 \mathrm{H}, J=8.3 \mathrm{~Hz})$, and $7.56(2 \mathrm{H}, J=8.3 \mathrm{~Hz}) \mathrm{ppm}$ as well as one triplet peak at $\delta 7.20 \mathrm{ppm}$. One singlet peak from hydroxyl proton appeared at $\delta_{\mathrm{H}} 11.93 \mathrm{ppm}$. Identification of the product using ${ }^{13} \mathrm{C}-\mathrm{NMR}$ (JOEL, JNM ECA $500 \mathrm{MHz}$ ) showed aryl carbons at $\delta_{c} 96,106,110,117,137$, and $155 \mathrm{ppm}$. The peak at $\delta_{\mathrm{C}} 179$ came from the carbonyl group while the peak at $\delta 155 \mathrm{ppm}$ was the peak for the carbon next to hydroxyl group.

Based on spectroscopy analyses, it could be stated that the reaction of 2-aminoxanthone with $\mathrm{NaNO}_{2} / \mathrm{HCl}$ and $\mathrm{H}_{3} \mathrm{PO}_{4}$ had successfully produced 2-hydroxyxanthone. The reaction mechanism was presented in Fig. 4. 


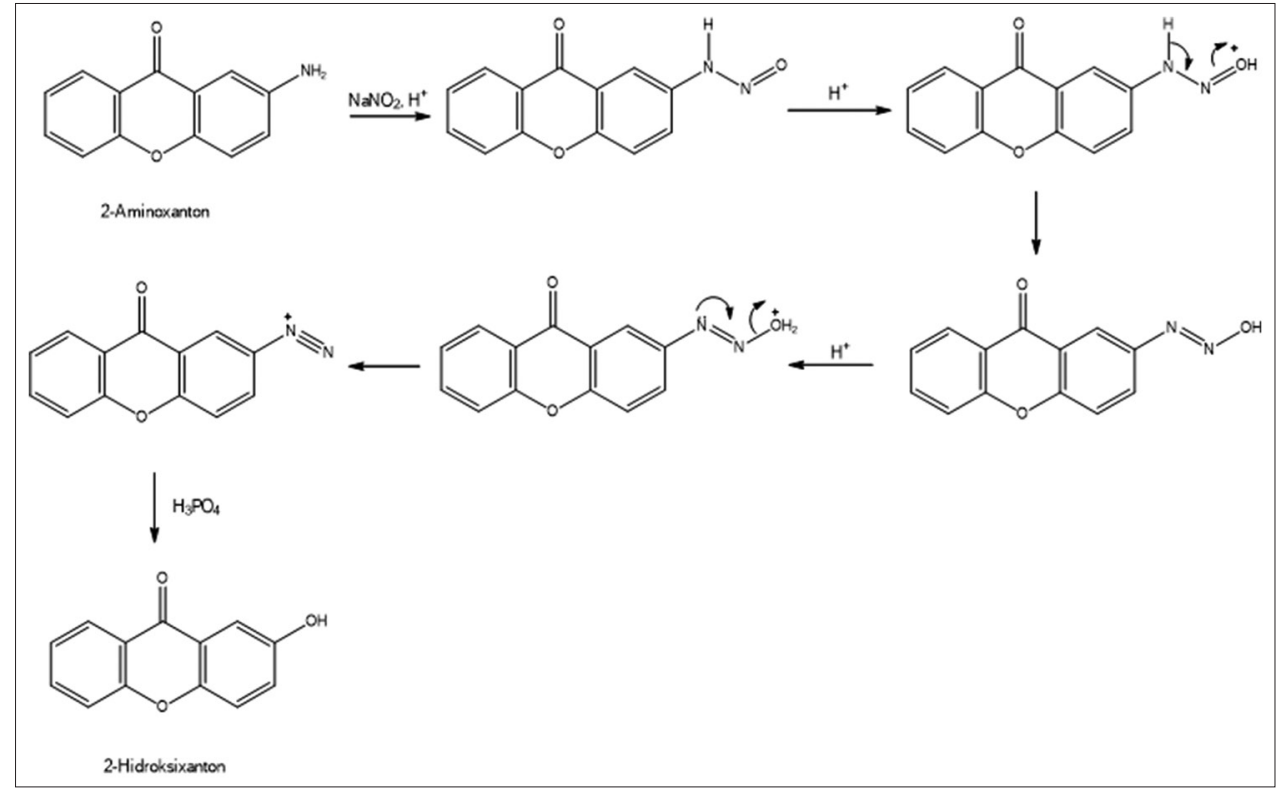

Fig. 4: Mechanism of synthesis of 2-hydroxyxanthone

\section{Calculation of 2-hydroxyxanthonerendement}

Their action products or rendements starting from nitration of xanthone to 2-hydroxyxanthone are shown in Table 1 . The data in this Table are stoichiometric calculation results for each step of the reactions.

\section{Synthesis of 2-nitroxanthone}

Xanthone $=4.9 \mathrm{~g}=\frac{4.9}{196}=0.025 \mathrm{~mol}$

2 -nitroxanthone product (theory) $=0.025 \mathrm{~mol}=0.025 \times 241=6.025 \mathrm{~g}$

Product (2-nitroxanthone) from xanthone (product of synthesis) $=4.2 \mathrm{~g}$

Rendement $=\frac{\text { Weight of product }}{\text { Weight of product(theory) }}$

$\times 100 \%=\frac{4.2 \mathrm{~g}}{6.025 \mathrm{~g}} \times 100 \%=69.71 \%$

\section{Synthesis of 2-aminoxanthone}

$2-$ nitroxanthone $=10 \mathrm{~g}=\frac{10}{241}=0.0414 \mathrm{mmol}$

2 -aminoxanthone product (theory) $=0.0414 \mathrm{mmol}=0.0414 \times 211 \mathrm{mg}=$ $8.7354 \mathrm{mg}$ Product (2-aminoxanthone) from synthesis $=6.884 \mathrm{mg}$

Rendement $=\frac{\text { Weight of product }}{\text { Weight of product(theory) }}$

$\times 100 \%=\frac{6.884 \mathrm{~g}}{8.7354 \mathrm{~g}} \times 100 \%=78.81 \%$

\section{Synthesis of 2-hydroxyxanthone}

2 -aminoxanthone $=10 \mathrm{mg}=\frac{10}{211}=0.0473 \mathrm{mmol}$

Product (2-hydroxyxanthone) from synthesized (theory) $=0.0473$ $\mathrm{mmol}=0.0473 \times 212=10.0276 \mathrm{mg}$
Product 2-hydroxyxanthone from 2-aminoxanthone $=7.0 \mathrm{mg}$.

$$
\begin{aligned}
& \text { Rendement }=\frac{\text { Weight of product }}{\text { Weight of product(theory) }} \\
& \times 100 \%=\frac{7.0 \mathrm{mg}}{10.0276 \mathrm{mg}} \times 100 \%=69.81 \%
\end{aligned}
$$

In general, synthesis of 2-hydroxyxanthone from xanthone can produce $38.35 \%$ of 2 -hydroxyxanthone which came from $69.71 \%$ of 2-nitroxanthone, $78.81 \%$ of 2 -aminoxanthone, and $69.81 \%$ of 2-hydroxyxanthone.

\section{Evaluation of antimalarial activity}

The in vitro antimalarial assay of 2-hydroxyxanthone was conducted using microscopic method with the incubation time of $48 \mathrm{hrs}$. The assay was carried out against $P$. falciparum strain of 3D7. The parasite was sensitive to chloroquine diphosphate. The parasite inhibitory activity was reported as $\mathrm{IC}_{50^{*}}$.

The antimalarial assay against P. falciparum was performed using candle jar methods $[15,21]$. The parasite culture was cultivated and then employed in the assay. From the in vitro assay, the $\mathrm{IC}_{50}$ value could be obtained. This value was the parameter indicating the potential of the 2-hydroxyxanthone as new antimalarial. In the antimalarial assay, the synthesized 2-hydroxyxanthone was dissolved in dimethyl sulfoxide (DMSO) to give concentrations of $10,1,0.1,0.01$, and $0,001 \mu \mathrm{g} / \mathrm{mL}$. The concentration of DMSO used was less than $0.5 \%$ as such concentration would not affect the parasite growth [19]. Distilled water was used as the negative control and used as the comparison in the calculation of parasite inhibitory activity of xanthone derivatives. In addition, chloroquine diphosphate was used as the positive control $[16,22]$ since P. falciparum strain of 3D7 was sensitive to chloroquine diphosphate. Moreover, the additional reason is that the drug is still applied as standard antimalarial drug in Indonesia.

The assay was performed in $48 \mathrm{hrs}$ as the asexual cycle of parasite in blood. In this phase, clinical symptoms of malaria such as fever and anemia were observed. Synchronization was carried out to make the parasite stadium to be the same. The inhibitory activity of each concentration was determined by calculating the inhibitory percentage of the test compound to the growth of P. falciparum. Parasitemia percentage was the amount of infected eritrosit compared to the total 
Table 2: $\mathrm{IC}_{50}$ value of some compounds against $P$. falciparum

\begin{tabular}{|c|c|c|c|c|c|c|}
\hline \multirow[t]{2}{*}{ Compound } & \multicolumn{5}{|c|}{$\%$ Inhibition of test dose $(\mu \mathrm{g} / \mathrm{mL})$} & \multirow[t]{2}{*}{$\mathrm{IC}_{50}(\mu \mathrm{g} / \mathrm{mL})$} \\
\hline & 10 & 1 & 0.1 & 0.01 & 0.001 & \\
\hline Xanthone & 63.01 & 55.17 & 37.62 & 33.22 & 5.02 & 0.688 \\
\hline Chloroquine diphosphate & 88.55 & 75.32 & 60.31 & 39.19 & 9.67 & 0.056 \\
\hline
\end{tabular}

$\mathrm{IC}_{50}$ : Half maximal inhibitory concentration, $P$. falciparum: Plasmodium falciparum

eritrosit. The total eritrosit was the amount of eritrosit in the field of view. The calculation of the average parasitemia percentage was required to calculate the parasite inhibitory percentage to the negative control using statistical method of probit analysis and finally to give $\mathrm{IC}_{50}$ value. Based on the results obtained from in vitro antimalarial assay, it showed that the $\mathrm{IC}_{50}$ value of 2-hydroxyxanthone was $0.44 \mu \mathrm{g} / \mathrm{mL}$, which is better than $\mathrm{IC}_{50}$ value of xanthone $(0.688 \mu \mathrm{g} / \mathrm{mL})$ as shown in Table 2 .

\section{CONCLUSION}

According to the results and discussion, it could be concluded that: (1) Synthesis of 2-hydroxyxanthone from xanthone was successfully done in three steps of synthetic reactions: 2-nitroxanthone, 2-aminoxanthone, and 2-hydroxyxanthone. These reactions had an overall yield of $38.35 \%$. In vitro antiplasmodial assay of 2-hydroxyxanthones against $P$. falciparum strain of $3 \mathrm{D} 7$ showed that the $\mathrm{IC}_{50}$ values of 2-hydroxyxanthone is $0.44 \mu \mathrm{g} / \mathrm{mL}$.

\section{ACKNOWLEDGMENTS}

We would like to thank to the Ministry of Research, Technology and Higher Education of the Republic of Indonesia for the research grant "Program of Doctoral Grant."

\section{REFERENCES}

1. WHO. Malaria. Available from: http://www.who.int/mediacentre/ factsheets/fs094/en. [Last accessed on 2013 Mar 23].

2. WHO. World Malaria Report 2009. Geneva: WHO; 2009.

3. Vial A. Reseacher de novalis molecules antipaludieneents, uneurdence, un espoir. Pathol Biol 1994;42:138-44.

4. Mustofa M. Malaria between hope and reality, speech inauguration of professor of Gadjah Mada university. Yogyakarta: Indonesia; 2009.

5. Sholikah EN. New Anti-Plasmodium N-Alkyl and N-Benzyl 1,10-Fenantrolin Derivatives: Study in vitro Activity, Cytotoxicity, Physical Properties of Chemistry, and Pharmaco-Kinetics Profile, Dissertation, Doctoral Program, Faculty of Medicine. Yogyakarta: Gadjah Mada University; 2010.

6. Rosmalena R, Prasasti VD, Hanafi M, Budianto E, Elya B. Lignan derivatives potential as Plasmodium falciparum lactate dehydrogenase inhibitors: Molecular docking approach of antiplasmodiul drug design. Int J Pharm Pharm Sci 2015;7(10):394-8.

7. Mahantheshappa SS, Satyanarayan Mahadevan KN, Bommegowda YD, Tangaraj M. Synthesis, antiplasmodial and ADMET studies of 4-methylamino-2phenylquinoline analogs. Int J Pharm Pharm Sci 2016;8(11):173-9.

8. Hay AE, Helesbeux JJ, Duval O, Labaied M, Grellier P, Richomme P. Antiplasmodiumxanthone from Calophylum caledonicum and Garcinia viellardii. Life Sci 2004;75:3077-85.
9. Miladiyah I, Jumina J, Haryana SM, Mustofa M. In silico molecular docking of xanthone derivatives as cyclooxygenase-2 inhibitor agents. Int J Pharm Pharm Sci 2017;9(3):98-104.

10. Wydyawaruyanti A, Khasanah U, Tumewu L, Ilmi H, Hafid AF, Tantular IS. Antimalarial activity and cytotoxicity study of ethanol extract and fraction from Alectronserratus leaves. Int J Pharm Pharm Sci $2015 ; 7(12): 250-3$

11. Hafid AF, Septiani RP, Fabriana LH, Febrianty N, Ranggaditya D, Wydyawaruyanti A. Antimalarial activity of crude extracts Artocarpus heterophyllus, Artocarpus altilis and Artocarpus camansi. Asian J Pharm Clin Res 2016;9(1):279-81.

12. Rahayu MK, Harmastuti N, Pamudji G, Klodengan D, Supargiyono S, Wijayanti MA. In vivo test of antimalarial activity from dichloromethaneethylacetate-methanol fractions of mundu's barks (Garcinia dulcis) in Swiss Webster mice. Asian J Pharm Clin Res 2017;10:113-5.

13. Kosela $\mathrm{S}, \mathrm{Hu} \mathrm{LH}$, Rachmatia T, Hanafi M, Sim KY. Dulxanthones F-H, three new pyranoxanthones from Garcinia dulcis. J Nat Prod 2000;63(3):406-7.

14. Hanafi M, Soemiati A, Kosela S, Leslie JH. Identification and Cytotoxic L1210 Cell Evaluation of Prenylatedpyranoxanthonoids from Garcinia dulcis Fruit (Gutteferae) n-Hexane Extract. Prosiding Seminar Internasional UGM; 2004.

15. Likhitwitayawuid K, Chanmahasathien W, Ruangrungsi N, Krungkrai J. Antiplasmodiumxanthones from Garcinia cowa. Plana Med 2000;64:70-2.

16. Wijayanti MA, Supargiyono S, Mustofa M, Sholikhah EN, Jumina J, Tahir I, et al. Heme Polymerization Inhibitory Activity (HPIA) of N-Alkyl and N-Benzyl-1,10-Phenanthroline Derivatives as Antiplasmodium, Proceeding of International Conference on Chemical Sciences (ICCS-20070: Jointly held by Department of Chemistry Gadjah Mada University and Department of Chemistry Universiti Sains Malaysia, Yogyakarta; 2007. p. 237-42.

17. Tomar N, Singh SV, Chottes LJ, Verma G, Anirban P, Singh V. Synthesis and anti-plasmodial activity of some novel chalcone derivatives. Asian J Pharm Res 2015;8(2):47-50.

18. No K, Noh Y. The synthesis of calix(4) arene. Bull Korean Chem Soc 1986;7:4.

19. Firdaus. Sintesis Seri Senyawa Aminokalisarenadan Penerapannyauntuk Menjerat Ion Logam Berat, $\mathrm{PhD}$ Thesis. Yogyakarta: Pascasarjana Universitas Gadjah Mada; 2008.

20. Harborne JB. Methode of Phytopharmaca, Guide Modern Way of Analyzing Plants, Translation Kosasih Padmawinata and Iwang Sudiro. Bandung: ITB; 1987.

21. Amanatie A, Jumina J, Mustofa M, Hanafi M. Development of new xanthone compound derivatives from Garcinia dulcis root as antiplasmodium. Research Report on Incentive Grant of Applied Research in the Field of Health and Pharmaceutical Technology Year II and III). Yogyakarta: Research Institute of Yogyakarta State University; 2009.

22. Naidoo JM. Novel Methodology for the Synthesis of Xanthones, Tesis. Johannesbur: Witwatersrand University; 2009. 